\title{
Gambaran Histologi Jaringan Tulang Ekstremitas Biawak Air (Varanus salvator) dengan Metabolic Bone Disease
}

\section{Histological Finding of Extremity Bone Tissue in Monitor Lizard (Varanus salvator) with Metabolic Bone Disease}

\author{
Febriana Hawa Prameswari ${ }^{1 *}$, Arimbi², Maya Nurwartanti Yunita ${ }^{2}$, Hani \\ Plumeriastuti $^{2}$, Aditya Yudhana ${ }^{3}$, Muhammad Thohawi Elziyad Purnama ${ }^{4}$ \\ ${ }^{1}$ Mahasiswa, ${ }^{2}$ Departemen Patologi Veteriner, ${ }^{3}$ Departemen Parasitologi Veteriner, ${ }^{4}$ Departemen Anatomi \\ Veteriner, Fakultas Kedokteran Hewan, Universitas Airlangga \\ *Corresponding author: febriana.hawa.prameswari-2015@ fkh.unair.ac.id
}

\begin{abstract}
Abstrak
Biawak air berjenis kelamin betina, berusia tiga bulan dengan berat badan $1.2 \mathrm{~kg}$ diambil dari suatu penangkaran, mengalami kelumpuhan selama tiga hari dan didiagnosa menderita metabolic bone disease. Eutanasia dan nekropsi dilakukan untuk mengamati gambar mikroskopis dari jaringan tulang. Sampel tulang diambil dari tujuh tulang ekstremitas yaitu os scapula, humerus, radius, ulna, femur, tibia, dan fibula. Pengamatan mikroskopis menunjukkan aktivitas sel osteoklas yang berlebihan dalam jaringan kompak, jaringan tulang rawan abnormal berada di antara jaringan tulang kompak dewasa, serta beberapa jaringan tulang rawan yang mengandung jaringan lemak. Hal ini menyebabkan tulang kompak kehilangan kepadatan tulang dan membuat struktur tulang biawak air menjadi sulit untuk regenerasi dengan baik sehingga pertumbuhan tulang pada biawak air menjadi terhambat. Hal ini menyebabkan biawak air kesulitan untuk berjalan atau mengalami kelumpuhan. Pemeriksaan kalsium dan fosfor dalam darah ditemukan ketidakseimbangan.
\end{abstract}

Kata kunci: Varanus salvator, metabolic bone disease, tulang ekstremitas, patologi

\begin{abstract}
A female monitor lizard, three month y.o. weighing $1.2 \mathrm{~kg}$ from breeder, has been paralyzed for three days and diagnosed with metabolic bone disease. Euthanize and necropsy performed to observed microscopic images of bone tissue. Bone samples taken from seven limb bones include scapula, humerus, radius, ulna, femur, tibia, and fibular. The microscopic observations showed excessive osteoclast cell activity in the compact tissue, in the other hand was found cartilage tissue that was not supposed to be between mature compact bone tissue, some cartilage tissue containing adipose. This causes the compact bone to lose bone density and make the lizard bone structure to be difficult to regenerate properly so that the growth of monitor lizards is inhibited, this causes make the lizards difficult to walked or paralyzed. Based on examination of calcium and phosphorus in the blood founded an imbalance.
\end{abstract}

Keywords: Varanus salvator, metabolic bone disease, extremity bone, pathology

Received: 15 Agustus 2019

Revised: 17 November 2019

Accepted: 11 Desember 2019

\section{PENDAHULUAN}

Biawak adalah kadal besar dari genus Varanus. Hewan ini berasal dari Afrika, Asia dan Oceania (wilayah geografis atau geopolitis yang terdiri dari sejumlah kepulauan yang terletak di Samudra Pasifik dan sekitarnya), tetapi sekarang ditemukan juga di Amerika sebagai spesies invasive (spesies yang bukan spesies asli tempat tersebut) (Sprackland, 1992).
Biawak memiliki leher yang panjang, ekor dan cakar yang kuat, dan anggota tubuh yang berkembang baik. Panjang dewasa spesies yang masih ada berkisar dari $20 \mathrm{~cm}$ pada beberapa spesies, hingga lebih dari $3 \mathrm{~m}$ pada komodo, pada Varanus yang telah punah yaitu Megalania ( $V$. priscus) panjang tubuhnya mencapai lebih dari $7 \mathrm{~m}$. Sebagian besar biawak berkeliaran di atas tanah, tetapi terkadang juga dikenal sebagai pemantau di atas pohon. Sebagian besar biawak 
adalah karnivora, memakan telur, reptil yang lebih kecil, ikan, burung dan mamalia kecil, beberapa juga makan buah dan tumbuhtumbuhan, tergantung di mana biawak ini tinggal (Bauer, 1998; Hamid dkk., 2018).

Kerangka appendikular, didefinisikan sebagai tungkai dan struktur pendukungnya. Tulang appendikular dari bagian depan adalah os phalanges, metacarpals, carpals, radius, ulna, humerus, procoracoid, interclavicle, clavicle dan scapula. Tulang ekstremitas bagian belakang termasuk os phalanges, metatarsal, tarsal, tibia, fibula, femur, ilieum, ischium, dan pubis (Kardong, 2014).

Biawak air termasuk kategori Appendiks II dalam daftar CITES (The Convention on International Trade in Endangered Species of Wild Fauna and Flora) (Gumilang dkk., 2003). Biawak air dapat diperdagangkan di pasar internasional dengan kuota yang telah ditetapkan. Hasil survei menunjukkan bahwa lebih dari satu juta biawak air diambil dari alam setiap tahun untuk dikonsumsi, dengan jumlah terbesar berasal dari Indonesia, khususnya Sumatera dan Kalimantan (Jenkins dan Broad, 1994). Jika eksploitasi Biawak air terus terjadi, akan mengakibatkan penurunan jumlah populasi biawak di alam dan tidak menutup kemungkinan Biawak air akan dikategorikan dalam Appendiks I CITES seperti halnya pada $V$. komodoensis (Mahfud dkk., 2017).

Metabolic Bone Disease (MBD) atau juga bisa disebut fibrous osteodystrophy, osteomalacia, secondary nutritional hyperparathyroidism, osteoporosis, atau rakitis merupakan masalah nutrisi yang paling sering terlihat pada reptil. MBD adalah dampak dari ketidakseimbangan kalsium dan fosfor dalam tubuh yang menyebabkan melemahnya struktur rangka serta tulang pada reptil. MBD dapat menyebabkan tremor berulang, kelemahan parah, dan patah tulang (Barten, 1993).

Reptil yang memakan serangga atau tanaman, beresiko menderita MBD, yang disebabkan oleh ketidakseimbangan kadar kalsium, fosfor, dan vitamin D di dalam tubuh. Biawak termasuk karnivora yang terkadang memakan serangga dan tumbuhan. Hal ini yang membuat biawak lebih rentan terserang MBD di antara jenis kadal besar lainnya (Bayless, 2014).

\section{METODE}

Alat - alat yang digunakan dalam pembuatan preparat histopatologi antara lain gelas objek, gelas penutup, tissue cassette, cetakan blok paraffin, Sakura ${ }^{\circledR}$ Automatic Tissue Processor, Sakura ${ }^{\circledR}$ Tissue Embedding Console, inkubator, mikrotom, mikroskop cahaya Olympus BHI, dan kamera Handphone. Untuk pengambilan darah digunakan spuit dengan needle dan tabung STT serta alat bedah untuk nekropsi.

Bahan-bahan yang digunakan untuk pembuatan preparat Histopat adalah Buffered Neutral Formalin 10\%, xylol, alkohol bertingkat (70\%, 80\%, 90\%), alkohol absolut, lithium karbonat, air hangat dan pewarna Mayer Haematoksilin - Eosin (Hamid dkk., 2019).

Desain penelitian ini menggunakan metode penelitian deskriptif yaitu suatu penelitian yang dilakukan dengan tujuan utama untuk mendeskripsikan kejadian-kejadian penting yang terjadi pada masa kini.

Penelitian ini adalah penelitian studi kasus yang dilakukan dengan cara meneliti suatu unit tunggal. Unit tunggal disini yang digunakan adalah jaringan tulang ekstremitas pada seekor biawak air yang terserang MBD. Unit yang menjadi kasus tersebut secara mendalam dianalisis baik dari segi yang berhubungan dengan keadaan kasus itu sendiri, faktor-faktor yang mempengaruhi, maupun kejadian-kejadian khusus yang muncul sehubungan dengan kasus. Meskipun di dalam studi kasus ini yang diteliti hanya berbentuk unit tunggal, namun dianalisis secara mendalam.

Persiapan awal yang dilakukan adalah melakukan uji kode etik hewan coba untuk mendapatkan penelitian yang sesuai prosedur dan animal welfare. Setelah itu dilakukan pemeriksaan fisik pada biawak yang diduga terserang MBD berdasarkan gejala klinis untuk menegakkan bahwa sampel yang didapat positif terserang MBD. Perlu dilakukan pengambilan darah untuk melihat kadar kandungan kalsium dan fosfor dalam darah. Tahap terakhir 
dilakukan eutanasia dan nekropsi pada biawak yang positif tersrang MBD untuk keperluan pembuatan preparat histopat.

\section{HASIL DAN PEMBAHASAN}

Berdasarkan penelitian yang dilakukan, anamnesa dan data yang didapat dari pemilik penangkaran biawak adalah jenis kelamin betina, berumur tiga bulan, dengan berat $1.2 \mathrm{~kg}$ mengalami kelumpuhan selama tiga hari. Beberapa ekstremitas digiti anterior sinister mengalami pembusukan dan nekrosis. Pemilik sering memberikan pakan dengan campuran sayur dan buah-buahan dan di kandangkan dalam kandang yang tertutup tanpa sinar matahari. Pada pemeriksaan fisik yang dilakukan oleh dokter hewan diketahui bahwa kondisi umum biawak tidak dapat berjalan dengan normal, membrana mukosa sangat pucat, ada benjolan disekitar tungkak kaki, serta mengalami diare sedang.

Sedangkan pada pemeriksaan kalsium dan fosfor dalam darah yang dilakukan di Laboratorium dinyatakan bahwa hasil dari kalsium total adalah 13.6 dan fosfor adalah 10.4. Sedangkan untuk perbandingan normal kalsium dan fosfor adalah $2: 1$, atau harga normalnya 30 : 15 , dimana dari uji laboratorium di temukan ketidakseimbangan antara perbandingan kalsium dan fosfor dalam darah biawak yang diuji.

Dari hasil pemeriksaan fisik serta hasil pemeriksaan uji laboratorium sementara biawak dapat diduga positif MBD, namun butuh tindakan lanjutan seperti dilakukannya euthanasi dan pembedahan untuk pemeriksaan patologisnya.

Temuan mikroskopik histopatologi dari beberapa tulang biawak air yang terserang MBD tampak pada Gambar 1. MBD sering terjadi pada reptil. MBD sebenarnya bukan entitas penyakit tunggal, melainkan istilah yang digunakan untuk menggambarkan kumpulan gangguan medis yang mempengaruhi integritas dan fungsi tulang. Ada banyak penyakit tulang metabolik yang mempengaruhi hewan dan manusia. Setiap patologi yang memengaruhi tulang reptil secara keseluruhan disebut MBD (Hall, 2005).
Fraktur pada reptil sering terjadi, biasanya karena MBD. Kekurangan nutrisi primer seperti MBD adalah yang paling umum. Secara khusus, fraktur patologis sering terjadi sebagai akibat Nutrisi Sekunder Hiperparatiroidisme yang merupakan kekurangan kalsium diet, fosfor berlebihan atau defisiensi paparan sinar ultraviolet dan vitamin D3 (Fowler, 1978).

Berdasarkan gambaran makroskopis yang didapat, dari luar tulang tampak normal namun saat di palpasi tekstur dari tulang lebih lunak dan rapuh. Ditemukan beberapa bagian tulang telah nekrosis. Gejala eksternal dari bentuk kronis penyakit MBD berkorelasi dengan perubahan fisiologis berbahaya yang terjadi dalam tubuh hewan. Tubuh mengkompensasi kekurangan kalsium serum dengan memobilisasi kalsium dari tulang. Tulang yang paling sering terkena adalah tulang kaki, tulang rusuk, rahang bawah, tulang datar tengkorak, dan tulang belakang vertebra. Seiring perkembangannya, kondisi garam kalsium dalam tulang digantikan oleh jaringan ikat fibrosa yang lebih lunak (osteodistrofi berserat). Ini menghasilkan tulang yang lentur (Frye, 1992).

Pada hasil pengamatan mikroskopis pada tulang ekstremitas ditemukan beberapa lesi yaitu banyaknya aktifitas sel osteoklas dalam jaringan kompak dan beberapa jaringan kartilago yang tidak seharusnya berada pada jaringan tulang dewasa. Sebagian jaringan kartilago tersebut berisi jaringan lemak yang memenuhi jaringan. Tampak pula pada lapangan pandang dengan perbesaran 10x mikroskop trinokuler, struktur kepadatan jaringan kompak menurun akibat banyaknya aktifitas sel osteoklas dan beberapa lakuna-lakuna di sekitarnya mengakibatkan jaringan tulang tampak seperti sponge. Namun pada jaringan tulang scapula banyak di jumpai zona ossifikasi karena tulang scapula adalah tulang rawan dan banyak mengandung kartilago dibanding tulang ekstremitas lainnya. Maka dari itu, untuk pengamatan jaringan tulang scapula hanya didapatkan gambaran normal dan proses ossifikasi tulangnya saja (Hartadi dkk., 2018).

MBD mengalami kontraksi serta hilangnya beberapa trabekula disebabkan karena hasil negatif dari proses pembentukan tulang, diikuti 

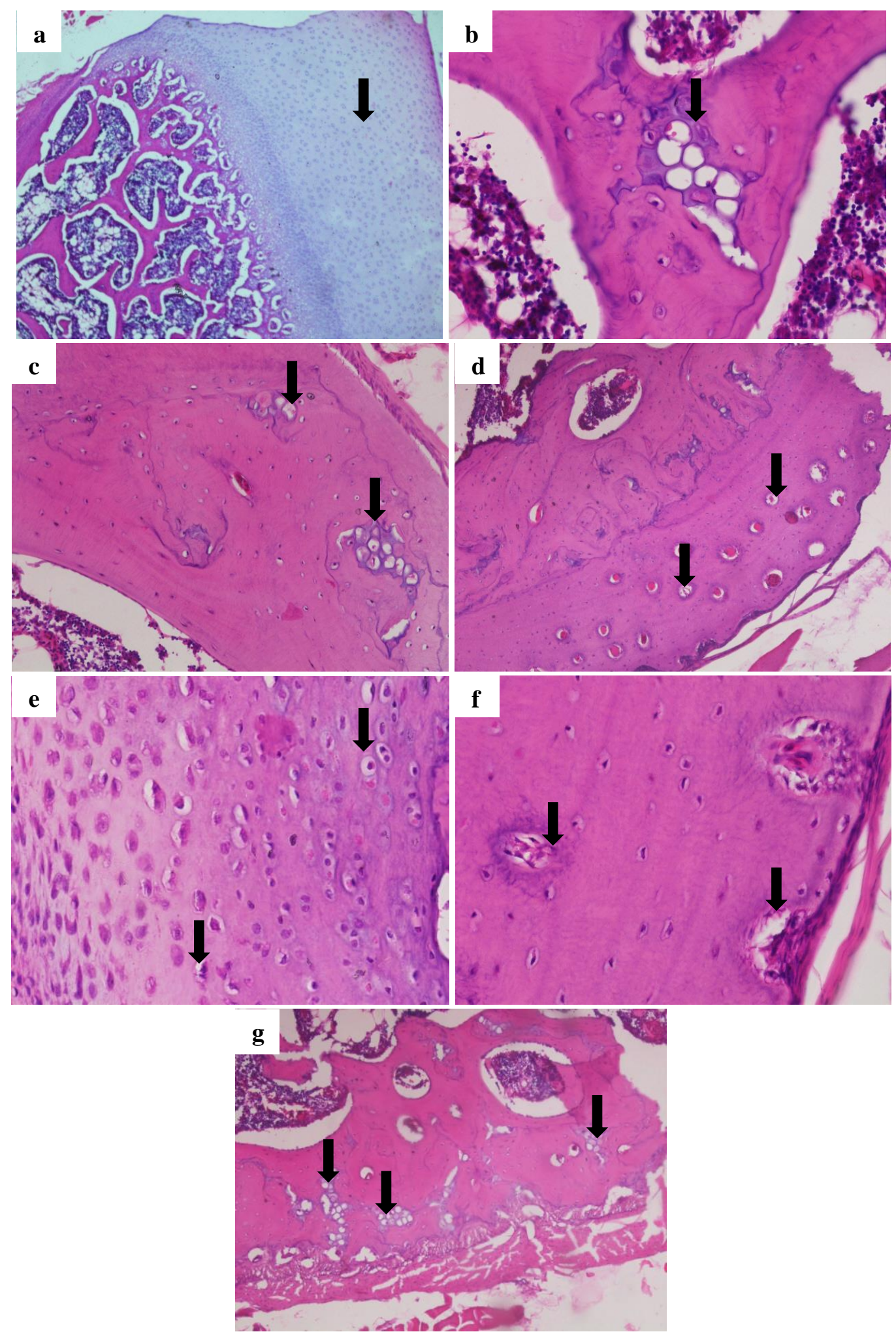

Gambar 1. (a) Os scapula terlihat zona ossifikasi normal; (b) Os humerus terlihat jaringan kartilago yang dipenuhi lemak; (c) Os radius terlihat banyak aktifitas sel osteoklas dan beberapa jaringan kartilago yang tidak seharusnya berada di jaringan kompak; (d) Os ulna terlihat banyak lakuna-lakuna yang membuat turunnya kepadatan jaringan kompak; (e) Os femur terlihat aktifitas sel osteoklas yang memenuhi sekitar jaringan kompak; (f) Os tibia terlihat banyak aktifitas sel osteoklas disekitar jaringan kompak; (g) Os fibula terlihat banyak jaringan kartilago yang tidak seharusnya berada pada jaringan kompak 
oleh penebalan trabekula lain untuk memenuhi mekanik ketegangan. Hal ini dapat diproduksi melalui resorpsi beberapa trabekula yang hanya akan bekerja pada sisa trabekula yang ada, dalam upaya untuk menolak peningkatan regangan mekanik yang baru dan dapat menebal secara adaptif. Penebalan akan terjadi akibat kekuatan yang beroperasi pada bagian itu. Trabekula tidak sepenuhnya rusak dan hanya terhubung ke seluruh sistem trabekular, sehingga kepentingan fungsional berkurang secara signifikan. Pada tahap resorpsi selanjutnya, trabekula tulang menipis, ketebalan berkurang menjadi hanya beberapa tulang lamela. Trabekula ini lebih rapuh karena osteolisis yang berlebihan. Ini terjadi karena penurunan jumlah trabekular seiring bertambahnya usia mewakili aspek ireversibel dari kehilangan tulang. Trabekula yang tersisa dan menipis dapat menguatkan perlawanan melalui penebalan yang terjadi setelah pembentukan tulang. Saat ketebalan trabekula berkurang dan rongga penyerapan yang tidak terlalu besar dapat menembus ketebalan trabekula, trabekula menghasilkan ketegangan yang meningkat di sekitarnya (Marcu et al., 2011; Islami dkk., 2018).

Sumsum tulang dan tulang memiliki ketergantungan secara fungsional. Modifikasi yang terjadi di tingkat sumsum tulang dengan penurunan dari seluler meningkatan jaringan lemak pada tingkat medular. Peningkatan jaringan lemak terjadi karena berkurangnya diferensiasi osteoblas dalam sel stroma prekursor yang mendukung diferensiasi jaringan lemak. Hal ini juga menunjukkan peningkatan jumlah sel lemak di tingkat sumsum tulang pada osteomalasia. Penyebab lain dapat berasal dari peningkatan jaringan lemak di medular terkait dengan vaskularisasi tulang. Sumsum tulang untuk melakukan fungsinya secara optimal seperti juga tulang tergantung pada darah yang tersedia. Pada osteoporosis, pengurangan aliran darah di tulang bisa terjadi, kepadatan mineral tulang dan osteopenia. Pentingnya hubungan antara perfusi darah dalam jaringan tulang dan sumsum tulang. Penurunan suplai darah pada tingkat medular diikuti oleh peningkatan jaringan lemak dari sumsum tulang (Oppenheimer \& Snodgrass, 1980).

Pemeriksaan kalsium dan fosfor dalam darah menunjukkan hasil kalsium total adalah 13.6 dan fosfor adalah 10.4. Sedangkan untuk perbandingan normal kalsium dan fosfor adalah $2: 1$, atau harga normalnya $30: 15$, dimana dari hasil uji laboratorium di temukan ketidakseimbangan antara perbandingan kalsium dan fosfor dalam darah biawak yang diuji karena jauh dari harga normal keduanya.

Pada ketidakseimbangan yang signifikan dalam Ca dan P mengakibatkan kelenjar kecil di leher reptil distimulasi untuk mengeluarkan sebuah hormon yang menyebabkan tulang kehilangan $\mathrm{Ca}$ yang disimpan, $\mathrm{Ca}$ kemudian dimasukkan dalam plasma darah dan cairan dalam jaringan, yang akhirnya Ca hilang dalam urin. Jika kehilangan $\mathrm{Ca}$ tidak terkontrol dan $\mathrm{Ca}$ yang hilang tidak diganti, hasilnya adalah suatu kondisi disebut MBD. Tanda-tanda awal kelainan ini adalah anggota tubuh yang secara bertahap membengkak. Tulang menjadi sangat lunak dan jaringan otot yang melemas. Ketika tulang ekstremitas terpengaruh terjadi pembengkakan dan ketimpangan. Dalam kasus ekstrim, otot polos berkedut, kejang dan kasus yang paling parah yaitu kelumpuhan serta kematian dapat terjadi (Fredrick, 1997).

Biawak yang digunakan dalam penelitian ini masih berumur sekitar tiga bulan. Maka terbilang masih sangat muda dan sebagian tulangnya masih dalam masa pertumbuhan. Penyakit metabolik pada tulang yang paling sering menyerang hewan muda yaitu osteomalacia, namun bila tidak diobati dan dibiarkan hingga tua penyakit ini dapat disebut dengan osteoporosis (Saggese, 2009).

\section{KESIMPULAN}

Biawak air yang terdiagnosa MBD memiliki intensitas tulang sangat lunak saat dipalpasi serta tulang tampak rapuh. Berdasarkan pengamatan mikroskopis menunjukkan adanya aktifitas sel osteoklas berlebihan pada jaringan kompaknya, ditemukan adanya jaringan kartilago yang tidak seharusnya berada diantara jaringan tulang 
kompak yang telah matang, dan beberapa jaringan kartilago berisi lemak didalamnya.

\section{UCAPAN TERIMA KASIH}

Penulis mengucapkan terima kasih kepada Puskeswan Kecamatan Licin, Banyuwangi.

\section{DAFTAR PUSTAKA}

Barten, S.L. 1993. The Medical Care of Iguanas and Other Common Pet Lizards. Exotic Pet Medicine. VCNA: Small Animal Practice, 23(6), 1213-1249.

Bauer, A.M. 1998. Encyclopedia of Reptiles and Amphibians. ed. Cogger, H.G., Zweifel, R.G. Academic Press. San Diego, Hal: 157.

Bayless, M.K. 2004. "The Local Names of Pacific Monitor Lizards (Sauria: Varanidae) of Oceania \& Indo-Malaysia, Excluding Australia". Micronesia, 37(1), 49-55.

Fowler, M.E. 1978. Metabolic bone disease, pp. 55-76 in Zoo And Wild Animal Medicine. M.E. Fowler, ed. Philadelphia, W.B. Saunders Co.

Fredric, F. 1997. The importance of calcium in relation to phosphorus, especially in folivorous reptiles. Proceed. Nutr. Soc., 56, 1105-1117.

Frye, F.L. 1992. Reptile Care: An Atlas of Diseases and Treatments. Malabar FL: Krieger Publishing. Hal: 637.

Hall, B.K. 2005. Bones and Cartilage: Developmental and Evolutionary Skeletal Biology. Elsevier Academic Press. London, Hal: 787.

Hamid, I.S., Aksono, E.B., Sukmanadi, M., Purnama, M.T.E. 2018. Antiangiogenesis activity test of tin leaf (Ficus carica L.) on the number of blood vessels and VEGF expression of chorioallantoic membrane of embryonated chicken eggs. Eur. J. Oncol. Pharm., 1(4), e00007.

Hamid, I.S., Ekowati, J., Purnama, M.T.E. 2019. Kaempferia galanga L. Inhibiting Effect on Vascular Endothelial Growth Factor (VEGF) and Cyclooxygenase-2 (Cox-2) Expression on Endothelium of Chorioallantoic Membrane. Indian Vet. J., 96(09), 80-82.

Hartadi, E.B., Dewi, W.K., Listyasari, N., Purnama, M.T.E. 2018. Studi Morfometrik pada Os Scapula Hewan Kelinci New Zealand White (Oryctolagus cuniculus). Jurnal Medik Veteriner, 1(3), 87-92.

Islami, D.N., Dewi, C.M.S., Triana, N.M., Purnama, M.T.E. 2018. Laporan Kasus: Otitis Eksterna dan Auricular Hematoma (Othematoma) pada Anjing Samoyed. J. Med. Vet, 1(3), 80-86.

Kardong, K.V. 2014. Vertebrates: Comparative Anatomy, Function, and Evolution, 7th Edition. McGraw-Hill. New York, pp: 794.

Mahfud, Winarto, A., Nisa, C. 2017. Morfologi Hemipenis Biawak Air (Varanus salvator bivittatus). Jurnal Sains Veteriner, 35, 112.

Marcu, F.L., Bogdan, F.L. 2011. The Histopathological Study of Osteoporosis. Rom. J. Morphol. Embryol., 321-325.

Openheimer， S.J., Snodgrass， G.J.A.I. 1980. Neonatal Rickets. Arch. Dis. Childhood., 55, 945-949.

Saggese, M.D. 2009. Clinical Approach to The Anemic Reptile. J. Exot. Pet Med., 18(2), 98-111.

Sprackland, R.G. 1992. Giant lizards. Neptune, NJ. T.F.H. Publications, pp: 61. 